УДК 355.255

Тарас Мацевко, кандидат психологічних наук, старший науковий співробітник Національна академія сухопутних військ імені гетьмана Петра Сагайдачного

ORCID ID 0000-0002-5424-847X

Олег Годованський, Національна академія сухопутних військ імені гетьмана Петра Сагайдачного

ORCID ID 0000-0003-0897-8375

DOI: $10.33099 / 2617-1775 / 2021-02 / 121-130$

\title{
АНАЛІЗ НОРМАТИВНО-ПРАВОВИХ АКТІВ 3 ПИТАНЬ ОЦІНЮВАННЯ РЕЗУЛЬТАТІВ НАВЧАННЯ ВИПУСКНИКІВ ВВНЗ, ЗА ПІДСУМКАМИ ЇХ СЛУЖБОВОЇ ДІЯЛЬНОСТІ
}

У статті проаналізовано нормативно-правові акти військової освіти (ВО) з питань оцінювання результатів навчання випускників ВВНЗ, за підсумками їх службової діяльності, як одного з елементів інформаційного забезпечення освітнього процесу. Визначено, щчо нормативно-правових актів, які системно розглядали весь перелік питань інформачійного забезпечення військової освіти щуодо очінки результатів навчання випускників ВВНЗ за підсумками їх службової діяльності на ией час не сформовано. Надано рекомендащії щзодо підготовки та зміни керівних документів, які регулюють підходи до оцінювання результатів навчання випускників ВВНЗ, за підсумками їх службової діяльності.

Ключові слова: інформаційне забезпечення; оцінювання результатів навчання; нормативні акти; військова освіта; професійні компетентності.

Постановка проблеми. Сучасні тенденції розвитку воєнного мистецтва i реалії відсічі збройної агресії РФ на Сході України потребують необхідності підвищення обороноздатності Держави та виступають каталізатором для удосконалення системи підготовки військових кадрів. Державі потрібні інтелектуально та професійно підготовлені фахівці, рівень підготовленості яких відповідає сучасним вимогам теорії та практики збройної боротьби, здатних на всіх етапах своєї професійної діяльності (військової кар'єри) оволодівати новими знаннями і вміннями, успішно керувати військами (силами) в бою (операції) та навчанням, вихованням, психологічною підготовкою особового складу в мирний $\mathrm{i}$ воєнний час, а також спроможними експлуатувати найскладніші системи сучасного військового озброєння та техніки 3 дотриманням вимог керівних документів, в т. ч. - стандартів НАТО в умовах бойової обстановки й повсякденної діяльності військ.

Актуальність дослідження визначається необхідністю удосконалення системи інформаційного забезпечення військової освіти у Збройних Силах України 3 питань оцінювання результатів навчання випускників ВВН3 за підсумками їх службової діяльності та створення ефективної системи інформаційного забезпечення якості підготовки військових фахівців у Збройних Сил України для своєчасного внесення змін в освітню діяльність ВВНЗ. 
Основою дослідження інформаційного забезпечення військової освіти у Збройних Силах України 3 питань оцінювання результатів навчання випускників ВВНЗ за підсумками їх службової діяльності є аналіз нормативноправових актів, які регламентують існуючу систему оцінювання їх діяльності в межах щорічного атестування та визначення напрямків щодо їх змін на основі створення єдиної методологічної схеми у вигляді співвідношення компетентності випускника ВВН3 з моделлю його професійної діяльності, 3 використанням отриманої інформації для удосконалення всієї системи військової освіти.

Аналіз останніх досліджень і публікацій. Інформаційне забезпечення $\epsilon$ невід`ємною складовою, яка впливає на ефективність освітнього процесу. Дослідження інформаційного забезпечення вищих навчальних закладів знайшло відображення у працях таких вчених, як Л. І. Антошкіна, Т. М. Боголіб, Н. І. Верхоглядова, Т. Є. Оболенська, В. Л. Плескач, проте в умовах сьогодення це питання потребує постійного дослідження та вдосконалення.

I. П. Босак та Є. М. Палига [1] трактують інформаційне забезпечення як наявність інформації, необхідної для управління процесами, що міститься у базах даних інформаційних систем. Під інформаційними системами розуміють системи зберігання, обробки, перетворення, передачі й оновлення інформації 3 використанням комп ютерної та іншої техніки.

На думку П. М. Сороки та Б. П. Сороки, інформаційне забезпечення - це сукупність форм документів різного призначення, нормативної бази та реалізованих рішень щодо обсягів, розміщення форм існування інформації, яка використовується в інформаційній системі під час її функціонування на об єкті управління.

Вони окреслили основні вимоги до інформаційного забезпечення [9]:

1. інформаційне забезпечення повинно бути достатнім для використання всіх функцій інформаційної системи, які автоматизуються;

2. для кодування інформації, що використовуються як на об`єкті управління, так і на вищому рівні, потрібно використовувати погоджені класифікатори;

3. інформаційне забезпечення цієї інформаційної системи повинно бути поєднане з інформаційним забезпеченням інших систем, з якими воно взаємодіє та ін.

Інший підхід до визначення інформаційного забезпечення можна побачити у наукових працях Л. Т. Ониксимова та Н. О. Петрини: «інформаційне забезпечення - це надання інформації, знайденої в ході робіт задля задоволення інформаційних потреб користувача і представленої у вигляді інформаційного продукту у зручному для споживача вигляді» [8].

На думку I. I. Доброскок, «інформаційне забезпечення - це цілісна технологічна навчальна система, що забезпечує інтеграцію технічного, дидактичного, користувального та інформаційно - освітнього середовищ, які створюють умови для виконання послідовності спільних дій суб'єктів навчання в умовах інформатизації освіти, орієнтованих на досягнення проектованих 
результатів професійної підготовки» $[4,38]$.

Отже, інформаційне забезпечення - сукупність процесів із підготовки й надання інформації для вирішення управлінських, наукових, технічних та інших завдань відповідності з етапами їх розв'язування.

Метою статті є аналіз діючих нормативно-правових актів 3 питань оцінювання результатів навчання випускників ВВНЗ, за підсумками їх службової діяльності, як одного з елементів інформаційного забезпечення освітнього процесу.

\section{Методи дослідження}

У статті використано загальнонаукові методи аналізу наукової літератури 3 досліджуваної проблеми, системний аналіз і синтез, індукція та дедукція, системний підхід до розв'язування проблем, класифікація, узагальнення та систематизація.

\section{Виклад основного матеріалу.}

Вхідним процесуальним елементом управління в системи військової освіти $€$ одержання інформації. У першу чергу - це нормативно-правові акти, що врегульовують суспільні відносини в галузі навчання, професійної підготовки громадян України. Стосовно вищої освіти головним з поміж інших є Закон України «Про вищу освіту»[5]. У ньому зокрема визначено, що якість вищої освіти це відповідність умов провадження освітньої діяльності та результатів навчання вимогам законодавства та стандартам вищої освіти, професійним та/або міжнародним стандартам (за наявності), а також потребам заінтересованих сторін і суспільства, що забезпечується шляхом здійснення процедур внутрішнього та зовнішнього забезпечення якості.

При цьому щодо оцінювання результатів навчання випускників ВВН3, за підсумками їх службової діяльності визначено таку форму як атестація це встановлення відповідності результатів навчання (наукової або творчої роботи) здобувачів вищої освіти вимогам освітньої (наукової, освітньо-творчої) програми та/або вимогам програми єдиного державного кваліфікаційного іспиту. Атестація осіб, які здобувають ступінь молодшого бакалавра, бакалавра чи магістра, здійснюється екзаменаційною комісією, до складу якої можуть включатися представники роботодавців та їх об'єднань, відповідно до положення про екзаменаційну комісію, затвердженого вченою радою закладу вищої освіти (наукової установи) [5].

Стандарти ВО формують основу інформаційного забезпечення підготовки фахівців і забезпечення якості в освітній сфері.

Систему стандартів вищої освіти складають стандарти вищої освіти професійні стандарт та освітні програми.

Зазначені стандарти є основою оцінки якості вищої освіти та професійної підготовки, а також якості освітньої діяльності вищих навчальних закладів незалежно від їх типів, рівнів акредитації та форм навчання.

Освітня програма повинна містити: перелік освітніх компонентів; їx логічну послідовність; вимоги до рівня освіти осіб, які можуть розпочати навчання за цією програмою; кількість кредитів СКТС, необхідних для виконання цієї програми, а також очікувані програмні результати навчання 
(компетентності), якими повинен оволодіти здобувач вищої освіти.

Освітні програми, що передбачають присвоєння професійних кваліфікацій, мають забезпечувати виконання вимог відповідних професійних стандартів (за наявності), якщо інше не передбачено законодавством.

Стандарт вищої освіти - це сукупність вимог до освітніх програм вищої освіти, які є спільними для всіх освітніх програм у межах певного рівня вищої освіти та спеціальності.

Стандарти вищої освіти розробляються для кожного рівня вищої освіти в межах кожної спеціальності відповідно до Національної рамки кваліфікацій і використовуються для визначення та оцінювання якості вищої освіти та результатів освітньої діяльності закладів вищої освіти (наукових установ), результатів навчання за відповідними спеціальностями.

Стандарт вищої освіти визначає такі вимоги до освітньої програми:

1) обсяг кредитів ЄКТС, необхідний для здобуття відповідного ступеня вищої освіти;

2) вимоги до рівня освіти осіб, які можуть розпочати навчання за цією програмою, та результатів їх навчання;

3) перелік обов'язкових компетентностей випускника;

4) нормативний зміст підготовки здобувачів вищої освіти, сформульований у термінах результатів навчання;

5) форми атестації здобувачів вищої освіти;

6) вимоги до створення освітніх програм підготовки за галуззю знань, двома галузями знань або групою спеціальностей (у стандартах рівня молодшого бакалавра), міждисциплінарних освітньо-наукових програм (у стандартах магістра та доктора філософії);

7) вимоги професійних стандартів (за їх наявності).

Порядок розроблення стандартів вищої освіти та внесення змін до них, а також здійснення контролю за їх дотриманням визначається Кабінетом Міністрів України. Органи управління, спираючись на Закон України «Про вищу освіту», інші закони адаптують їх до завдань і специфіки функціонування мережі ВВН3: перетворюють і передають одержану інформацію іншим елементам системи освіти. Одним 3 показників перетворення одержаної інформації може слугувати наказ Міністерства оборони України № 4 від 09 січня 2020 року «Про затвердження Положення про особливості освітньої діяльності у вищих військових навчальних закладах Міністерства оборони України та військових навчальних підрозділах закладів вищої освіти» [6].

Цей наказ, як управлінське рішення, забезпечує приведення у відповідність до Закону України «Про вищу освіту» нормативної бази щодо функціонування ВВНЗ ЗС України та вдосконалення процесу організації освітньої діяльності в системі військової освіти. Зокрема в цьому наказі визначається, що інформаційне забезпечення освітньої діяльності у ВВНЗ включає: наявність бібліотек, у яких розміщується навчальна та інша література, вітчизняні та закордонні фахові періодичні видання за спеціальностями підготовки або спорідненого профілю підготовки, періодичні наукові видання, інформаційні і довідкові матеріали, які забезпечують освітню, наукову і науково-технічну 
діяльність.

Наказом Міністерства оборони України від 27.11.2017 № 621, який має назву «Деякі питання управління вищими військовими навчальними закладами, військовими навчальними підрозділами закладів вищої освіти та військовими ліцеями», визначено розподіл основних завдань і функцій між структурними підрозділами Міністерства оборони України та Генерального штабу Збройних Сил України, іншими органами військового управління з питань управління військовою освітою [7]. Відповідно до цього розподілу основними завданнями та функціями Міністерства оборони України 3 питань управління військовою освітою зокрема $є$ :

організація роботи екзаменаційних та приймальних (відбіркових) комісій ВВН3 та під час проведення атестації випускників ВВН3, та вступної кампанії відповідно, прийняття рішення щодо вдосконалення їх роботи (діяльності);

організація спільно з Міністерством освіти і науки України розробки переліку галузей знань та спеціальностей підготовки військових фахівців, стандартів вищої військової освіти;

перевірка та аналіз якості освітньої діяльності ВВНЗ.

Серед основних завдань та функцій Генерального штабу Збройних Сил України з питань управління військовою освітою визначено такі елементи щодо інформаційного забезпечення оцінювання результатів навчання випускників ВВНЗ, за підсумками їх службової діяльності:

погодження стандартів вищої військової освіти та освітньо-професійних (освітньо-наукових) програм підготовки військових фахівців;

залучення фахівців Генерального штабу Збройних Сил України та органів військового управління до участі в перевірках якості організації освітнього процесу у ВВНЗ, повноти виконання навчальних планів і програм підготовки.

Департамент військової освіти, науки, соціальної та гуманітарної політики Міністерства оборони України відповідно до наданих повноважень організовує проведення атестації випускників ВВНЗ.

Керівники структурних підрозділів Міністерства оборони України, Генерального штабу Збройних Сил України та інших органів військового управління, яким безпосередньо підпорядковані ВВНЗ, відповідно до наданих повноважень відповідають за:

впровадження в освітній процес ВВНЗ досвіду бойових дій, участі у миротворчих операціях, бойової (оперативної) підготовки військ (сил);

своєчасність надання відгуків на випускників до ВВНЗ після року їх служби у військах (силах), врахування пропозицій з удосконалення освітнього процесу.

Керівники структурних підрозділів Міністерства оборони України, Генерального штабу Збройних Сил України, інших органів військового управління, які є замовниками на підготовку військових фахівців, відповідно до наданих повноважень, відповідають за:

контроль організації та якості підготовки військових фахівців, які готуються у ВВНЗ за їх замовленням, повноти виконання навчальних програм (за планами цих структурних підрозділів, що погоджуються із службовою 
особою, якій безпосередньо підпорядкований ВВН, і директором Департаменту військової освіти, науки Міністерства оборони України);

створення умов для якісної підготовки військових фахівців, які навчаються за їх замовленням, підвищення кваліфікації науково- педагогічних (педагогічних) та наукових кадрів у ВВН3;

визначення вимог до компетентності випускників ВВНЗ, які навчаються за ïх замовленням, розроблення професійних стандартів та освітньо-професійних програм їх підготовки, проведення аналізу змісту навчання та якості підготовки військових фахівців, зміст програм навчальних дисциплін та надання пропозицій щодо внесення необхідних змін (оновлення) до зазначених програм;

відповідність навчальних планів і програм навчальних дисциплін вимогам освітньо-професійних програм підготовки у ВВНЗ, їх інтеграцію з підготовкою і завданнями військ (сил);

впровадження в освітній процес ВВНЗ досвіду бойових дій, участі у миротворчих операціях, бойової (оперативної) підготовки військ (сил);

забезпечення ВВНЗ, у яких здійснюється підготовка військових фахівців за ïх замовленням, необхідним озброєнням та військовою технікою, військовотехнічним майном, постійна участь у вдосконаленні та розвитку матеріальнотехнічної бази, впровадженні сучасних освітніх та інформаційних технологій відповідно до номенклатури озброєння і майна, особливостей завдань та специфіки застосування виду (роду) військ;

своєчасне надання відгуків на випускників до ВВНЗ після року їх служби у військах (силах), надання пропозицій для вдосконалення змісту навчальних планів і програм.

Щодо керівних документів, які безпосередньо визначають порядок оцінювання результатів навчання випускників ВВН3, за підсумками їх службової діяльності, то слід відзначити їх обмежений характер. Так відповідно до Директиви Генерального штабу Збройних Сил України від 06.03.2014 № ДГШ-6 Про затвердження Табеля термінових донесень Збройних Сил України 3 кадрових питань та підготовки військових фахівців, було визначено форму, порядок відпрацювання та терміни подачі військовими частинами відгуку на випускника після року служби у військах (форма відгуку надана у додатку Г), проте відповідно до Директиви Генерального штабу Збройних Сил України від 05.10.2018 № ДГШ-15 ці положення були скасовані [2; 3]. При цьому, в наказі Міністра оборони України від 10.04.2009 № 170 Про затвердження Інструкції про організацію виконання Положення про проходження громадянами України військової служби у Збройних Силах України із змінами, внесеними згідно з Наказами Міністерства оборони редакції 25,09,2019 року та Методичних рекомендаціях 3 порядку організації $\mathrm{i}$ проведення атестування військовослужбовців Збройних Сил України, які затверджені директором Департаменту кадрової політики Міністерства оборони України від 19.04.2017 № 328 (зі змінами від 12.10.2018 № 226/490, від 01.10.2019 № 226/4372 ), зазначено, що після закінчення підготовки за денною формою навчання випускників військових закладів вищої освіти після року військової служби (через рік після закінчення, оформлюється відгук на 
випускника військового закладу вищої освіти). Маємо певну неузгодженість у керівних документах.

\section{Висновки та перспективи подальших досліджень.}

Таким чином, нормативно-правових актів, які системно розглядали весь перелік питань інформаційного забезпечення військової освіти щодо оцінки результатів навчання випускників ВВНЗ за підсумками їх службової діяльності на цей час не сформовано. Діючі керівні документи щодо атестації особового складу персоналу не враховують особливостей молодих офіцерів і їх рівень підготовки у ВВНЗ.

Основним недоліком отримання інформації відповідно до діючих керівних документів є значна суб'єктивність. Крім цього, критерії та показники оцінювання результатів навчання випускників ВВНЗ за підсумками їх службової діяльності спрямовуються в ОВУ кадрового забезпечення, рідше у ВВН3, отже, мають обмежене використання для всієї системи інформаційного забезпечення військової освіти.

На підставі проведеного дослідження щодо підходів до оцінювання результатів навчання випускників ВВНЗ, за підсумками їх службової діяльності можна надати такі рекомендації:

1. Доцільно відпрацювати керівний документ (Інструкція) щодо унормування процесу збору, обробки, аналізу та розповсюдження інформації щодо оцінювання результатів навчання випускників ВВН3 та ВНП ЗВО, за підсумками їх службової діяльності.

Цей документ має бути розроблений Департаментом військової освіти i науки у взаємодії з Департаментом кадрової політики. Та затверджений наказом Міністерства оборони України. В основі розробки має бути оцінка компетентностей випускника під час виконання службової діяльності.

Доцільно визначити структурний підрозділ Департаментом військової освіти і науки МА України, який відповідатиме за отримання, обробку, аналіз, узагальнення та розповсюдження отриманої інформації зацікавленим суб'єктам системи військової освіти, а також визначити порядок внесення змін, на основі узагальненої інформації, у стандарти вищої освіти, освітньо-професійні програми, інші інформаційно-організаційні документи системи військової освіти.

2. Доцільно внести зміни у Директива Генерального штабу Збройних Сил України від 06.03.2014 № ДГШ-6 Про затвердження Табеля термінових донесень Збройних Сил України з кадрових питань та підготовки військових фахівців, щодо відновлення в Табелі термінових донесень Збройних Сил України з кадрових питань та підготовки військових фахівців форми відгуку на випускника військового навчального закладу після року служби.

3. На підставі розробленого документу (п.1.), внести зміни у Наказ МО України від 27.11.2017 року № 621 «Деякі питання управління вищими військовими навчальними закладами, військовими навчальними підрозділами закладів вищої освіти та військовими ліцеями».

В подальшому передбачається проведення моніторингу відповідності отриманих оцінок ефективності професійної діяльності випускників і 
корегування методів та механізмів оцінювання.

\section{ЛІТЕРАТУРА}

1. Босак І. П. Інформаційне забезпечення управління підприємством: економічний аспект / І. П. Босак, С. М. Палига // Регіонал. економіка. - 2007. - № 4. - С. 193-195.

2. Директива Генерального штабу Збройних Сил України від 06.03.2014 № ДГШ-6 Про затвердження Табеля термінових донесень Збройних Сил України з кадрових питань та підготовки військових фахівців.

3. Директива Генерального штабу Збройних Сил України від 05.10.2018 № ДГШ-15 Про затвердження Змін до Табеля термінових донесень Збройних Сил України 3 кадрових питань та підготовки військових фахівців.

4. Доброскок I. Інформаційне забезпечення освітнього середовища майбутніх соціальних педагогів як засіб активізації й інтенсифікації управління навчальним процесом у ВНЗ / І. Доброскок // Рідна шк. - 2012. - № 89. - С. 37-41.

5. Закон України «Про вищу освіту» 2014 року № 1556-VII в редакції від 25.09.2020 [Електронний ресурс] / Режим доступу: https://zakon.rada.gov.ua/laws/show/1556-18\#Text. Назва $з$ екрану.

6. Наказ Міністерства оборони України № 4 від 09 січня 2020 року «Про затвердження Положення про особливості освітньої діяльності у вищих військових навчальних закладах Міністерства оборони України та військових навчальних підрозділах закладів вищої освіти» [Електронний ресурс] / Режим доступу: https://zakon.rada.gov.ua/laws/show/z0250-20\#Text. Назва з екрану.

7. Наказ Міністерства оборони України від 27.11.2017 року № 621 «Деякі питання управління вищими військовими навчальними закладами, військовими навчальними підрозділами закладів вищої освіти та військовими ліцеями» [Електронний ресурс] / Режим доступу: https://www.mil.gov.ua/content/mou_orders/621_nm_2017.pdf. - Назва з екрану.;

8. Петрина Н. О. Інформаційне забезпечення процесів освіти і науки в умовах становлення інформаційного суспільства [Електронний ресурс] / Н.О.Петрина, Н. Т. Ониксимова. http://dspace.uabs.edu.ua/bitstream/123456789/2660/3/Petrina\%202.pdf. - Назва з екрану.

9. Сорока П. М. Інформаційний менеджмент : навч. посіб. / П. М. Сорока, Б. П. Сорока ; Відкритий міжнар. ун-т розвитку людини «Україна» . - Київ, 2008. - 535 с.

\section{REFERENCES}

1. Bosak I. P. Informatsiine zabezpechennia upravlinnia pidpryiemstvom: ekonomichnyi aspekt / I. P. Bosak, Ye. M. Palyha // Rehional. ekonomika. - 2007. - № 4. - S. 193-195.

2. Dyrektyva Heneralnoho shtabu Zbroinykh Syl Ukrainy vid 06.03.2014 № DHSh-6 Pro zatverdzhennia Tabelia terminovykh donesen Zbroinykh Syl Ukrainy z kadrovykh pytan ta pidhotovky viiskovykh fakhivtsiv.

3. Dyrektyva Heneralnoho shtabu Zbroinykh Syl Ukrainy vid 05.10.2018 № DHSh-15 Pro zatverdzhennia Zmin do Tabelia terminovykh donesen Zbroinykh Syl Ukrainy z kadrovykh pytan ta pidhotovky viiskovykh fakhivtsiv.

4. Dobroskok I. Informatsiine zabezpechennia osvitnoho seredovyshcha maibutnikh sotsialnykh pedahohiv yak zasib aktyvizatsii y intensyfikatsii upravlinnia navchalnym protsesom $\mathrm{u}$ VNZ / I. Dobroskok // Ridna shk. - 2012. - № 89. - S. 37-41.

5. Zakon Ukrainy "Pro vyshchu osvitu” 2014 roku № 1556-VII v redaktsii vid 25.09.2020 [Elektronnyi resurs] / Rezhym dostupu: https://zakon.rada.gov.ua/laws/show/1556-18\#Text. Nazva z ekranu.

6. Nakaz Ministerstva oborony Ukrainy № 4 vid 09 sichnia 2020 roku "Pro zatverdzhennia Polozhennia pro osoblyvosti osvitnoi diialnosti u vyshchykh viiskovykh navchalnykh zakladakh Ministerstva oborony Ukrainy ta viiskovykh navchalnykh pidrozdilakh zakladiv vyshchoi osvity" [Elektronnyi resurs] / Rezhym dostupu: https://zakon.rada.gov.ua/laws/show/z0250-20\#Text. - 
Nazva z ekranu.

7. Nakaz Ministerstva oborony Ukrainy vid 27.11.2017 roku № 621 "Deiaki pytannia upravlinnia vyshchymy viiskovymy navchalnymy zakladamy, viiskovymy navchalnymy pidrozdilamy zakladiv vyshchoi osvity ta viiskovymy litseiamy" [Elektronnyi resurs] / Rezhym dostupu: https://www.mil.gov.ua/content/mou_orders/621_nm_2017.pdf. - Nazva z ekranu.;

8. Petryna N. O. Informatsiine zabezpechennia protsesiv osvity i nauky $\mathrm{v}$ umovakh stanovlennia informatsiinoho suspilstva [Elektronnyi resurs] / N. O. Petryna, N. T. Onyksymova. Rezhym dostupu: http://dspace.uabs.edu.ua/bitstream/123456789/2660/3/Petrina\%202.pdf. - Nazva $\mathrm{z}$ ekranu.

9. Soroka P. M. Informatsiinyi menedzhment : navch. posib. / P. M. Soroka, B. P. Soroka; Vidkrytyi mizhnar. un-t rozvytku liudyny «Ukraina». - Kyiv, 2008. - 535 s.

\section{PЕЗЮМЕ}

Тарас Мацевко, кандидат психологических наук, старший научный сотрудник Национальная академия сухопутных войск имени гетмана Петра Сагайдачного

Олег Годованский,

Национальная академия сухопутных войск имени гетмана Петра Сагайдачного

\section{Анализ нормативно-правовых актов по вопросам оценивания результатов обучения выпускников ВВУЗов, по итогам их служебной деятельности}

В статье проанализированы нормативно-правовые акты военного образования по оценке результатов обучения выпускников ВВУЗов, по итогам их служебной деятельности, как одного из элементов информационного обеспечения образовательного процесса. Определено, что нормативно-правовые акты, которые системно рассматривают весь перечень вопросов информационного обеспечения военного образования по оценке результатов обучения выпускников ВВУЗов, в настоящее время, не сформированы. Дань рекомендации по подготовке и изменению руководящиих документов, регулирующих подходы $\kappa$ оценке результатов обучения выпускников ВВУЗов, по итогам их служебной деятельности.

Ключевые слова: информаџионное обеспечение; оченка результатов обучения; нормативные акты; военное образование; профессиональные компетентности.

\section{SUMMARY}

Taras Matsevko

PhD in Psychology, Senior Scientific Researcher Hetman Petro Sahaidachnyi National Army Academy

Oleh Hodovanskyi

Hetman Petro Sahaidachnyi National Army Academy

Analysis of normative legal acts on the assessment of the learning outcomes of graduates of the Higher Educational Institutions, based on the results of their service activities

The article analyzes the normative legal acts of military education on the assessment of the learning outcomes of graduates of the Higher Educational Institutions, based on the results of their service activities, as one of the elements of the information support of the educational process. legal acts that systematically consider the entire list of issues of information support for military 
education in assessing the learning outcomes of graduates of higher educational institutions, at present, have not been formed. Recommendations are given on the preparation and amendment of guidelines governing approaches to assessing the learning outcomes of graduates of military educational institutions, based on the results of their service activities.

Key words: information support; assessment of learning outcomes; regulations; military education; professional competencies.

Introduction. The basis of the study of information support for assessing the learning outcomes of graduates of military institutes of Ukraine is the analysis of legal acts. They regulate the existing system of evaluating the activities of servicemen during the annual certification. Legal acts need to be changed. They must comply with the new graduate evaluation model.

Purpose. The purpose of the article is to analyze the current regulations on the evaluation of learning outcomes of university graduates, based on the results of their official activities, as one of the elements of information support of the educational process.

Methods. The article uses general scientific methods of analysis of scientific literature on the researched problem, system analysis and synthesis, induction and deduction, system approach to problem solving, classification, generalization and systematization.

Results. Information support of military education does not have legal acts on the evaluation of training results of graduates of military institutes. The current guidance documents on the certification of personnel do not take into account the characteristics of young officers and their level of training.

Originality. The Department of Military Education and Science, together with the Department of Personnel Policy, should develop a guidance document on the evaluation of the learning outcomes of graduates of military institutes.

Directive of the General Staff of the Armed Forces of Ukraine dated March 6, 2014 № DGS-6 should be amended. It should define the forms of response to a graduate of a military institute after a year of service.

Conclusion. The subjectivity of the assessment of a graduate of a military institute is the main disadvantage of obtaining information now.

In addition, the criteria and indicators for evaluating the performance of a graduate of a military institute have limited use.

The study has the prospect of monitoring the relevance of assessments and the effectiveness of professional activities of graduates. 